\title{
Characterization of Alternaria isolates and reaction of potato genotypes to early blight
}

\author{
Caracterização de isolados de Alternaria e \\ reação de genótipos de batata à pinta preta
}

\begin{abstract}
Thayssa Vilela Miguel Alvarenga ${ }^{I}$ Silvia Regina Rodrigues de Paula Ribeiro ${ }^{{ }^{*}}$ Elaine Aparecida de Souza ${ }^{\mathrm{I}}$ Francielly de Cássia Pereira ${ }^{\mathrm{I}}$ César Augusto Brasil Pereira Pinto
\end{abstract}

\section{ABSTRACT}

Early blight is one of the most important fungal diseases of potato. The objective of this study was to evaluate the in vitro reaction of potato genotypes to the severity of early blight and compare the species Alternaria solani and Alternaria grandis, etiologic agents of disease, through the evaluation of physiological characteristics. Twenty-two genotypes of the Potato Breeding Program at UFLA, two cultivars, Aracy and Bintje, patterns of resistance and susceptibility, respectively were evaluated. For inoculation, three isolates of $\boldsymbol{A}$. grandis and two isolates of A. solani were used. Plantlets obtained in vitro were inoculated with a $5 \mathrm{~mm}$ diameter mycelial disk of isolates Alternaria spp. of. These were incubated in severity and classified according to the rating scale. Isolates of Alternaria spp. were evaluated for mycelial growth index (MGI) and for formation of mycelial compatibility groups (MCG). The methodology for evaluating the in vitro reaction of genotypes to severity of early blight was efficient for both isolates. The isolates of A. solani and A. grandis were similar in their aggressiveness. The isolates of A. grandis MGI's had higher, and therefore mycelium grew faster when compared to those isolated from A. solani. The occurrence of mycelial compatibility among isolates of $A$. solani and $A$. grandis indicated the possible occurrence of parasexual cycle.

Key words: Alternaria grandis, Alternaria solani, mycelial compatibility, aggressiveness, genetic resistance.

RESUMO

A pinta preta é uma das doenças fúngicas mais importantes da cultura da batata. O objetivo deste trabalho foi avaliar, in vitro, a reação de genótipos de batata à pintapreta e comparar as espécies Alternaria grandis e Alternaria solani, por meio da avaliação de características fisiológicas. Foram avaliados 22 genótipos do Programa de Melhoramento Genético de Batata da UFLA, sendo duas cultivares, padrões de resistência e suscetibilidade. Foram inoculados três isolados de A. grandis e dois de A. solani. As plântulas, obtidas in vitro, foram inoculadas com os isolados de Alternaria spp., incubadas e classificadas quanto à severidade. Os isolados de Alternaria spp. foram avaliados quanto ao indice de velocidade de crescimento micelial (IVCM) e a formação de grupos de compatibilidade micelial (GCM). A metodologia de avaliação precoce in vitro da reação dos genótipos à severidade da pintapreta foi eficiente para os isolados de ambas as espécies de Alternaria. Os isolados de A. grandis e A. solani apresentaram comportamento semelhante quanto à agressividade. Os isolados de A. grandis apresentaram IVCMs superiores e, portanto, crescimento micelial mais rápido. A ocorrência de compatibilidade micelial entre isolados de A. grandis e A. solani indica a possibilidade de ocorrência do ciclo parassexual.

Palavras-chave: Alternaria grandis, Alternaria solani compatibilidade micelial, agressividade, resistência genética.

\section{INTRODUCTION}

Early blight is one of the major fungal diseases of potato (Solanum tuberosum L.) and other Solanaceae. Up until 2009, it was believed that early blight in potato in Brazil was caused only by Alternaria solani, but after studies carried out by (RODRIGUES et al., 2010), the association of Alternaria grandis was confirmed for the disease. According to these authors, the main morphological characteristic that identifies the species is conidium body length, which may vary from 85 to $100 \mu \mathrm{m}$ in $\boldsymbol{A}$. solani, and from 102 to $184 \mu \mathrm{m}$ in $\boldsymbol{A}$. grandis.

Alternaria spp. has a short life cycle, favoring its rapid development and progress of the disease, thus making blight a difficult disease to

\footnotetext{
IPrograma de Pós-graduação em Genética e Melhoramento de Plantas, Universidade Federal de Lavras (UFLA), 37200-000, Lavras, MG, Brasil. E-mail: silviaribeiro@dbi.ufla.br. *Corresponding author.
} 
control (STRANDBERG, 1992). Among the control measures, genetic resistance has become the most effective and promising strategy, due to reduction in production costs and lower environmental impact.

The Potato Breeding Program at the Universidade Federal de Lavras (UFLA) (Federal University of Lavras, Lavras, MG, Brazil) handles a large number of clones. However, evaluation of all of them in the field is hampered by the need to obtain a large number of inoculum, dependency on favorable weather conditions for disease development, and time of inoculation (60 to 80 days after planting). Moreover, it is very difficult to obtain sporulation in $\boldsymbol{A}$. solani. Thus, the use of an effective strategy for artificial inoculation would permit early selection on a large scale, aiming blight resistance. From the selected clones, field assessments can be made which will contribute to accelerate the breeding process in order to obtain resistant cultivars.

Quantification of the morphological variability of pathogens within their populations is also an important tool because it allows inferences in regard to evolutionary potential and its implications for management practices, such as development of breeding programs and strategic use of fungicides (MA et al., 2003). According to these authors, this variability probably results from genetic variations among isolates.

This study was used to evaluate potato genotypes from the Potato Breeding Program at UFLA for resistance to early blight using the method proposed by VAN DER WAALS et al. (2004) and to compare isolates from the species $\boldsymbol{A}$. solani and $\boldsymbol{A}$. grandis for their physiological characteristics.

\section{MATERIALS AND METHODS}

In vitro evaluation of reaction of potato genotypes to the severity of early blight

The experiment was conducted in a completely randomized design (CRD) in a $22 \times 5$ factorial arrangement, with five replicates. Thus, 22 potato genotypes (19 clones from the breeding program at UFLA and tree cultivars: Cupido, Aracy, resistant control and Binjte, susceptible control) and five isolates of Alternaria spp. (three isolates of $\boldsymbol{A}$. grandis - Ag 220, Ag 169, Ag 260 - supplied by the Universidade Federal de Viçosa, and two isolates of A. solani - As 14, As 22 - from the fungal collection of the Plant Disease Resistance Laboratory at UFLA were evaluated. Alternaria species were identified by conidia size according RODRIGUES et al. (2010).
Artifitial inoculation was carried out according with methodology of VAN DE WAALS et al. (2004). Budding tubers were used to obtain potato plantlets in vitro. Budings were transfered to test tubes with MS culture medium (MURASHIGE \& SKOOG, 1662 ) and incubated in growing room with controlled conditions of light and temperature. Alternaria spp. isolates colonies were grown in PDA medium and incubated at $25 \pm 2^{\circ} \mathrm{C}$ in BOD. A mycelial disc from each isolate was inoculated onto five plantlets of each potato genotype obtained through tissue culture. After five days of incubation, the seedlings were evaluated for resistance to blight, according to the rating scale proposed by VAN DER WAALS et al. (2004), where $0=$ no symptoms, $1=$ slight leaf necrosis, $2=$ whole leaf necrosis, $3=$ necrosis on the leaf, stem and other plant parts. According to the scale, the seedlings with scores below 2 are considered resistant, and those with scores greater than or equal to 2 are considered susceptible.

The data were subjected to analysis of variance using the statistical program MSTAT - C (1991) and the mean values were compared by the SCOTT \& KNOTT (1974) test, $\mathrm{P} \leq 0.05$.

Comparison between the species $\boldsymbol{A}$. solani and $\boldsymbol{A}$. grandis

Mycelial growth index (MGI)

The experiment was conducted in a completely randomized design (CRD) with three replicates per isolate, with each replicate represented by a plate. Colony diameters were measured every 72 hours over a period of 15 days from the time of inoculation. Measurements taken were used to obtain the MGI. The MGI measurements were compared by the test SCOTT \& KNOTT (1974), $\mathrm{P} \leq 0.05$, and linear regression equations were obtained based on the mycelial growth of each isolate.

\section{Mycelial compatibility groups (MCG) \\ For evaluation of mycelial compatibility} groups (MCG), the method of VAN DER WAALS et al. (2004), with modifications, was used. Mycelial discs with a $5 \mathrm{~mm}$ diameter were transferred to PDA (Potato Dextrose Agar) plates in an arrangement of two discs per plate spaced at $3 \mathrm{~cm}$. They were kept in a (BOD) growth chamber at $25 \pm 2{ }^{\circ} \mathrm{C}$ in the dark for fifteen days.

The pairs of confronted isolates were considered incompatible when a line of contact or reaction zone was observed. Three replications were performed for each pair of combinations. 


\section{RESULTS AND DISCUSSION}

In vitro evaluation of reaction of potato genotypes to the severity of early blight

Among the 22 genotypes evaluated it was observed genotypes in all classes of the grading scale proposed by VAN DER WAALS et al. (2004) (Figure 1). Significant differences occurred for potato genotypes and for genotypeisolate interaction. The isolates showed no significant difference, indicating that they have the same level of aggressiveness. Results from this study corroborated those obtained in a greenhouse by RODRIGUES \& MIZUBUTI (2009), in which potato plants inoculated with $\boldsymbol{A}$. grandis and $\boldsymbol{A}$. solani showed similar symptoms and illness intensity.

The Scott \& Knott test, for reaction of potato genotypes to the severity of early blight was performed for each isolate (Table 1). For isolates Ag169, Ag260, As22 and As14, the genotypes were grouped into two distinct groups. Group A consisted of genotypes that were considered resistant and group B contained genotypes classified as susceptible. The isolate $\mathrm{Ag} 220$ allowed better discrimination of potato genotypes by classifying them into three groups and the groups A and B would be classified as resistant.

The results showed that the mechanisms of resistance of potato genotypes to early blight for both species are probably the same. This is the first report of a pathogenicity test in vitro using isolates from $\boldsymbol{A}$. grandis clones developed in Brazil.

Overall, $70 \%$ of the genotypes evaluated were classified as resistant when inoculated with different isolates of Alternaria spp. Only the clone PRM 267 behaved differently when inoculated with the different species (Table 1). This clone, when inoculated with isolates of $\boldsymbol{A}$. grandis, was classified as resistant and when inoculated with isolates of $\boldsymbol{A}$. solani, was considered susceptible.

The in vitro evaluation methodology was effective in the discrimination of potato genotypes in resistant and susceptible classes. In field studies by PINTO et al. (2002) several clones were evaluated for resistance to early blight and these results were also coincident with the in vitro evaluation conducted in this study. Clones PRM 51, PRM 177, PRM 516 and PRM 530, which showed resistance in the field, have also been classified in vitro, as resistant according to VAN DER WAALS et al. (2004) scale. Similarly the clones DGN 39-08, DGN 24-02, DGN 27-03 and DGN 21-10 were considered resistant, exhibiting the same in vitro behavior when compared with the data observed in the field by NEDER et al. (2010). These authors inoculated the fungus 40 and 50 days after planting, using the methodology described by REIFSCHNEIDER (1987). In this methodology the

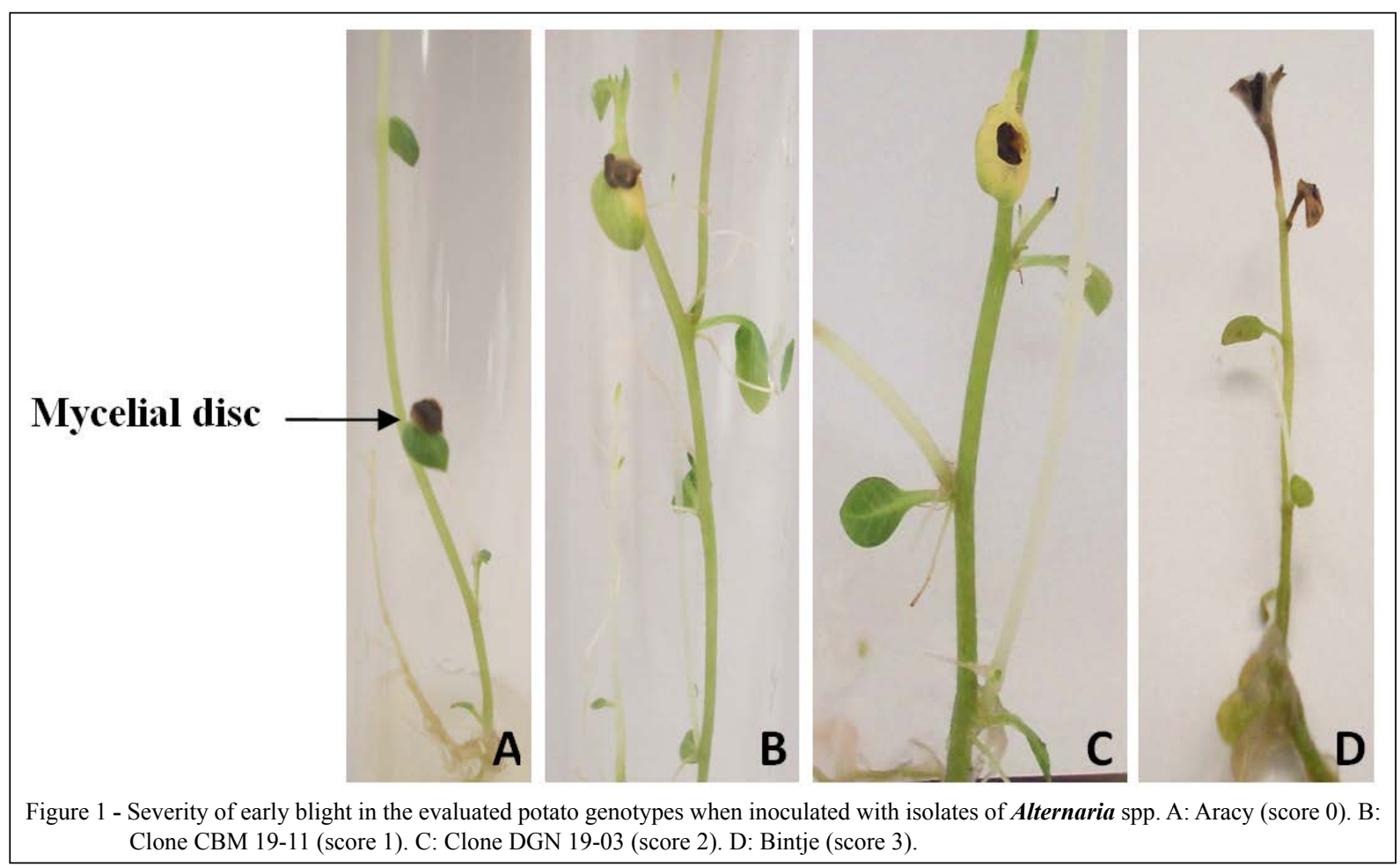

Ciência Rural, v.46, n.10, out, 2016. 
Table 1 - Average severity scores of early blight in potato genotypes for the five isolates of Alternaria spp.

\begin{tabular}{|c|c|c|c|c|c|}
\hline GENOTYPES & Ag 169 & Ag 220 & Ag 260 & As 22 & As14 \\
\hline PRM 51 & $1.40^{\mathrm{a}^{*}}$ & $1.80^{\mathrm{b}}$ & $1.48^{\mathrm{a}}$ & $1.20^{\mathrm{a}}$ & $1.40^{\mathrm{a}}$ \\
\hline CBM 24-06 & $1.56^{\mathrm{a}}$ & $1.00^{\mathrm{a}}$ & $1.48^{\mathrm{a}}$ & $1.44^{\mathrm{a}}$ & $1.28^{\mathrm{a}}$ \\
\hline DGN 12-03 & $1.60^{\mathrm{a}}$ & $1.20^{\mathrm{a}}$ & $1.48^{\mathrm{a}}$ & $1.40^{\mathrm{a}}$ & $1.20^{\mathrm{a}}$ \\
\hline DGN 24-02 & $1.20^{\mathrm{a}}$ & $1.00^{\mathrm{a}}$ & $1.40^{\mathrm{a}}$ & $1.24^{\mathrm{a}}$ & $1.20^{\mathrm{a}}$ \\
\hline PRM 177 & $1.48^{\mathrm{a}}$ & $1.48^{\mathrm{b}}$ & $1.40^{\mathrm{a}}$ & $1.24^{\mathrm{a}}$ & $1.44^{\mathrm{a}}$ \\
\hline PRM 516 & $1.20^{\mathrm{a}}$ & $1.60^{\mathrm{b}}$ & $1.40^{\mathrm{a}}$ & $1.20^{\mathrm{a}}$ & $1.40^{\mathrm{a}}$ \\
\hline PRM 530 & $1.56^{\mathrm{a}}$ & $1.28^{\mathrm{a}}$ & $1.48^{\mathrm{a}}$ & $1.48^{\mathrm{a}}$ & $1.56^{\mathrm{a}}$ \\
\hline DGN 39-08 & $1.24^{\mathrm{a}}$ & $1.28^{\mathrm{a}}$ & $1.48^{\mathrm{a}}$ & $1.24^{\mathrm{a}}$ & $1.20^{\mathrm{a}}$ \\
\hline DGN 19-03 & $2.68^{b}$ & $3.16^{\mathrm{c}}$ & $2.92^{b}$ & $3.40^{\mathrm{b}}$ & $2.96^{\mathrm{b}}$ \\
\hline DGN 27-03 & $1.60^{\mathrm{a}}$ & $1.60^{\mathrm{b}}$ & $1.56^{\mathrm{a}}$ & $1.40^{\mathrm{a}}$ & $1.20^{\mathrm{a}}$ \\
\hline DGN 21-10 & $1.72^{\mathrm{a}}$ & $1.48^{\mathrm{b}}$ & $1.48^{\mathrm{a}}$ & $1.48^{\mathrm{a}}$ & $1.72^{\mathrm{a}}$ \\
\hline CBM 04-48 & $1.28^{\mathrm{a}}$ & $1.48^{\mathrm{b}}$ & $1.48^{\mathrm{a}}$ & $1.48^{\mathrm{a}}$ & $1.28^{\mathrm{a}}$ \\
\hline СТВ 38-38 & $1.40^{\mathrm{a}}$ & $1.48^{\mathrm{b}}$ & $1.80^{\mathrm{a}}$ & $1.60^{\mathrm{a}}$ & $1.60^{\mathrm{a}}$ \\
\hline CUPIDO & $3.40^{\mathrm{b}}$ & $3.20^{\mathrm{c}}$ & $3.40^{\mathrm{b}}$ & $3.40^{\mathrm{b}}$ & $3.20^{\mathrm{b}}$ \\
\hline PRM 110 & $3.00^{\mathrm{b}}$ & $3.00^{\mathrm{c}}$ & $2.80^{\mathrm{b}}$ & $2.80^{\mathrm{b}}$ & $2.92^{b}$ \\
\hline ARACY & $1.20^{\mathrm{a}}$ & $1.24^{\mathrm{a}}$ & $1.48^{\mathrm{a}}$ & $1.00^{\mathrm{a}}$ & $1.48^{\mathrm{a}}$ \\
\hline BINTJE & $3.16^{\mathrm{b}}$ & $3.20^{\mathrm{c}}$ & $3.60^{\mathrm{b}}$ & $3.16^{\mathrm{b}}$ & $3.40^{\mathrm{b}}$ \\
\hline PRM 475 & $4.00^{\mathrm{b}}$ & $3.40^{\mathrm{c}}$ & $2.92^{\mathrm{b}}$ & $3.20^{\mathbf{b}}$ & $2.92^{\mathrm{b}}$ \\
\hline PRM 267 & $1.00^{\mathrm{a}}$ & $1.00^{\mathrm{a}}$ & $1.40^{\mathrm{a}}$ & $2.00^{\mathbf{b}}$ & $2.40^{\mathrm{b}}$ \\
\hline CBM 09-10 & $3.40^{\mathrm{b}}$ & $3.00^{\mathrm{c}}$ & $2.92^{\mathrm{b}}$ & $3.00^{\mathbf{b}}$ & $3.00^{\mathrm{b}}$ \\
\hline CBM 19-11 & $1.40^{\mathrm{a}}$ & $1.72^{\mathrm{b}}$ & $1.80^{\mathrm{a}}$ & $1.96^{\mathrm{a}}$ & $1.96^{\mathrm{a}}$ \\
\hline СТВ 40-12 & $3.16^{\mathrm{b}}$ & $3.00^{\mathrm{c}}$ & $2.60^{\mathrm{b}}$ & $3.00^{\mathrm{b}}$ & $2.40^{\mathrm{b}}$ \\
\hline
\end{tabular}

${ }^{*}$ Within the same column, means with the same letter are not significantly different according to the Scott \& Knott test, $\mathrm{P} \leq 0.05$.

inoculation is carried out using a mixture of early blight infected dried leaves which are grounded and spread on plants canopy in the field. Therefore, it is not possible to determine the virulence of the pathogen isolates and the Alternaria species involved.

The clones CTB and CBM have not yet been evaluated for severity of early blight. Of these clones, only CBM 09-10 and CTB 40-12 were considered susceptible, while CBM 4-48, CBM 2406, CBM 19-11 and CTB 38-38 were considered resistant. It is noteworthy that clones $\mathrm{CBM}$ are considered promising for the breeding program at UFLA, since they have desirable agronomic traits such as high dry matter content of tubers, high percentage of large tubers and, especially, heat tolerance, a very important feature for planting potato in Brazil.

In general, evaluation for resistance to early blight is carried out in the field and in greenhouse, where plants are subjected to both natural infection and artificial inoculation by conidia (NACHMIAS et al., 1988; DUARTE et al., 2013 and 2014). However, the latter is limited by the difficulty in producing sufficient spores of Alternaria spp. for inoculation of genotypes on a large scale. The method of inoculation and in vitro evaluation of blight used in this study, proved to be efficient due to the coincidence of results of field and in vitro experiments. Therefore, it is an effective and reliable tool, which can be used in breeding programs because it allows the evaluation of a large number of genotypes, contributing to the achievement of resistant cultivars.

Comparison between the species $\boldsymbol{A}$. solani and $\boldsymbol{A}$. grandis Mycelial growth index (MGI)

For MGI the five isolates were classified into two distinct groups, divided according to the species (Table 2). A. grandis isolates grew faster when compared to the isolates $\boldsymbol{A}$. solani revealing the existence of variability between the two species for this trait.

The observed range of MGI, for isolates of $\boldsymbol{A}$. solani, was $0.7 \mathrm{~cm} \mathrm{day}{ }^{-1}$ to $1.80 \mathrm{~cm} \mathrm{day}^{-1}$, which is consistent with the data in literature on the extent of mycelial growth rates (MICHEREFF et al., 2003; KUMAR, 1998). Initial mycelial growth of the isolates of $\boldsymbol{A}$. grandis was superior to $\boldsymbol{A}$. solani, which can be confirmed by the $\mathrm{b}_{0}$ estimates obtained in the regression equations (Figure 2).

Although the isolates of $\boldsymbol{A}$. grandis presented greater MGI they did not have difference as related to aggressiveness to potato plants compared to 
Table 2 - Average of mycelial growth index, MGI, $\left(\mathrm{cm} \cdot\right.$ day $\left.^{-1}\right)$ of the five isolates of Alternaria spp.

\begin{tabular}{ll}
\hline Isolates & MGI \\
\hline $\operatorname{Ag} 169$ & $0.66^{\mathrm{a}^{*}}$ \\
$\operatorname{Ag} 260$ & $0.65^{\mathrm{a}}$ \\
$\operatorname{Ag} 220$ & $0.65^{\mathrm{a}}$ \\
As 22 & $0.35^{\mathrm{b}}$ \\
As 14 & $0.34^{\mathrm{b}}$ \\
\hline
\end{tabular}

*Means with the same letter are not significantly different according to the Scott \& Knott test, $\mathrm{P} \leq 0.05$. the $\boldsymbol{A}$. solani isolates since the disease severity was similar for both species (Table 1).

\section{Mycelial compatibility groups (MCG's)}

It was evaluated 15 combinations of pairs of the five isolates of Alternaria spp. Of this total, approximately $87 \%$ showed mycelial compatibility. The rest of the pairs appeared in the reaction zone, and were; therefore, incompatible. According to SAUPE (2000), the results obtained in this study are consistent given that incompatible interactions may frequently occur among the isolates of the same population as well as with distinct populations.
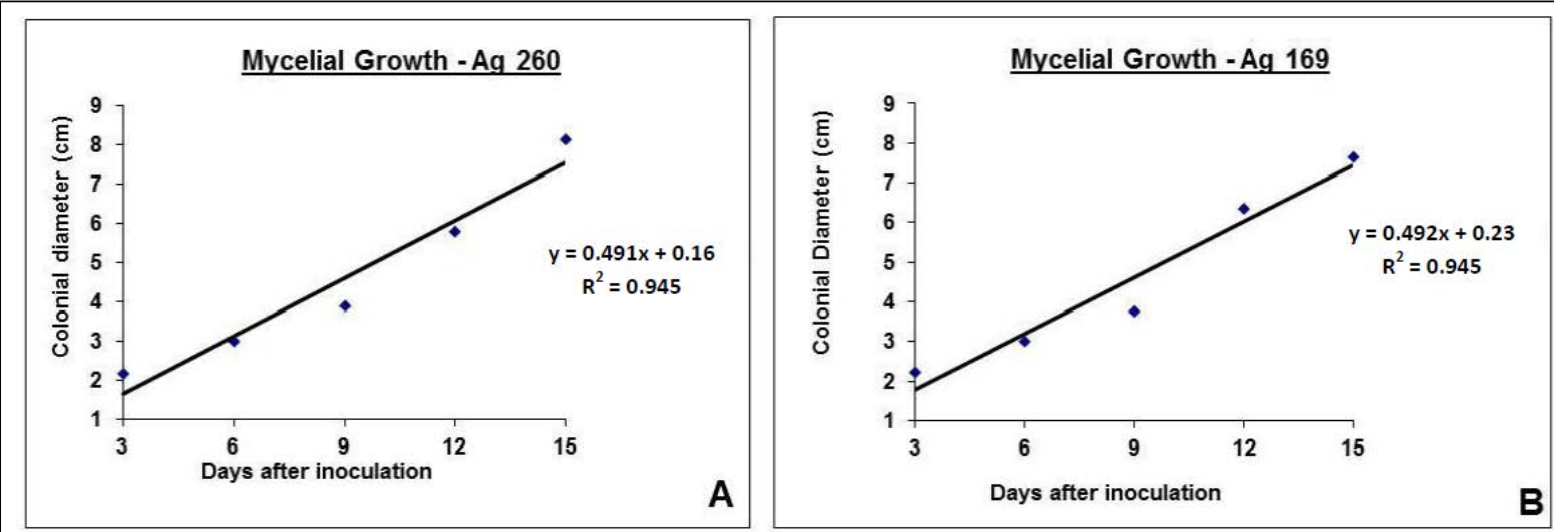

A
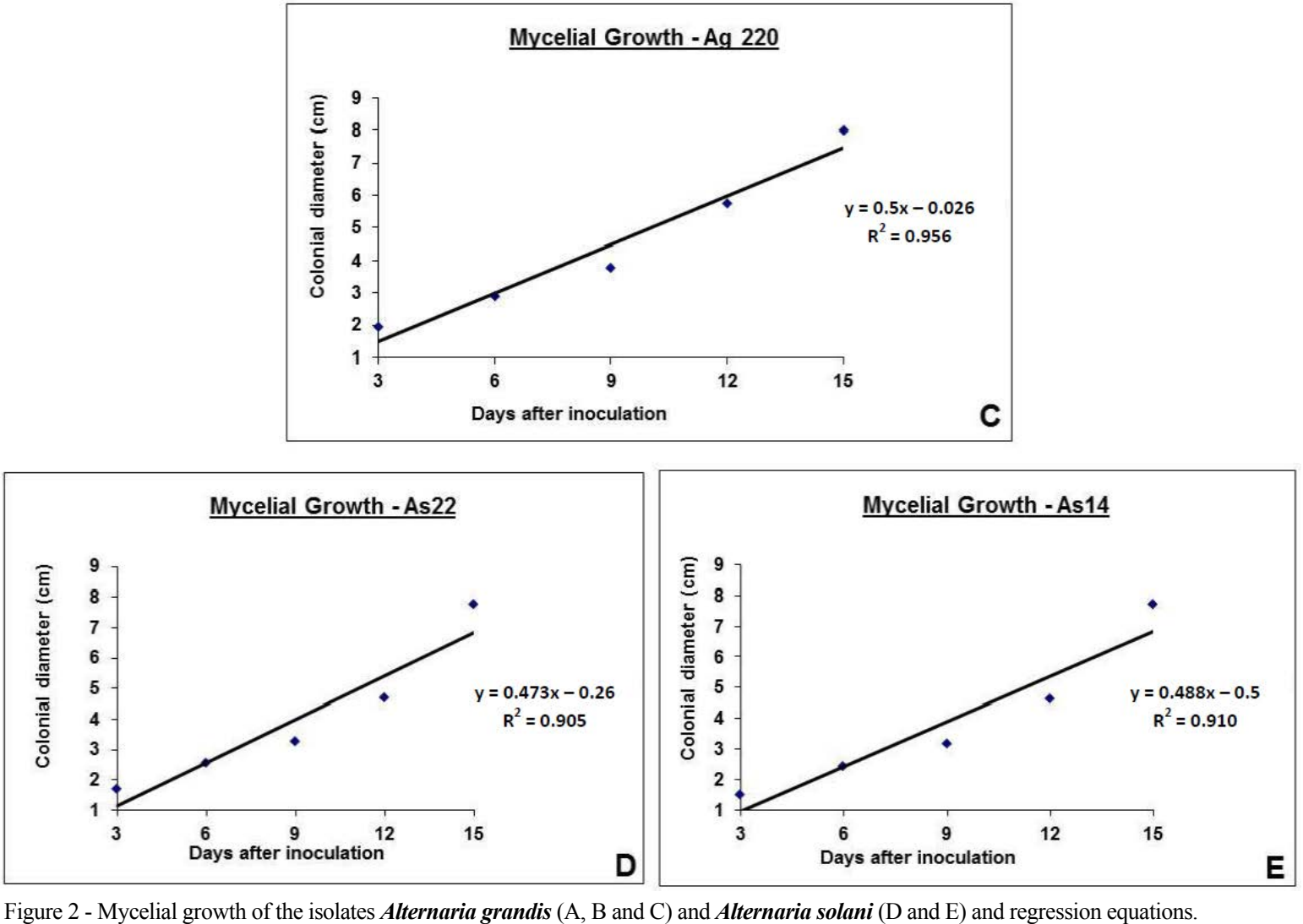

Figure 2 - Mycelial growth of the isolates Alternaria grandis (A, B and C) and Alternaria solani (D and E) and regression equations.

Ciência Rural, v.46, n.10, out, 2016. 
VAN DER WAALS et al. (2004), when analyzing the mycelial compatibility groups of 53 isolates of $\boldsymbol{A}$. solani, observed the formation of six groups containing various isolates and 13 isolates did not form groups.

According to GLASS et al. (2000), the reactions of incompatibility may be related to a self-defense system, responsible for limiting the passage of infectious elements and/or preventing exploitation by maladapted nuclei. Mycelial compatibility is a prerequisite for the occurrence of the parasexual cycle, a mechanism of genetic recombination in fungi that do not reproduce sexually as those in the genus Alternaria (STEWART et al., 2013). According to PONTECORVO (1956) after formation of the heterokaryon from two genetically distinct haploid mycelia recombined via crossovers and haplodization generated genetically variable progeny. This cycle offers an evolutionary alternative for the introgression of novel genetic material and complementation of dysfunctional gene copies in asexual species. The occurrence of parasexual cycle as mechanism of recombination among Alternaria alternata isolates of a subpopulation from citrus has been suggested (STEWART et al., 2013) and evidences has been observed in other asexual fungi species (ZEIGLER et al., 1997; MCGUIRE et al., 2005; MILGROOM et al., 2009). The occurrence of mycelium compatibility between isolates of $\boldsymbol{A}$. grandis and $\boldsymbol{A}$. solani gives evidence that there is the possibility of a parasexual cycle occurring between these species.

\section{CONCLUSION}

The method of early in vitro evaluation of the reaction of potato genotypes to early blight was efficient for the isolates of both $\boldsymbol{A}$. grandis and $\boldsymbol{A}$. solani and allowed discrimination of resistant and susceptible clones. The isolates of $\boldsymbol{A}$. grandis and A. solani were similar in their aggressiveness. The isolates of $\boldsymbol{A}$. grandis presented superior MGI's and; therefore, faster growth when compared to isolates of A. solani. The occurrence of mycelial compatibility between isolates of $\boldsymbol{A}$. solani and $\boldsymbol{A}$. grandis indicated the possible occurrence of a parasexual cycle.

\section{ACKNOWLEDGEMENTS}

The authors are grateful to Coordenação de Aperfeiçoamento de Pessoal de Nível Superior (CAPES), Conselho Nacional de Desenvolvimento Científico e Tecnológico (CNPq) and Fundação de Amparo a Pesquisa do Estado de Minas Gerais (FAPEMIG) for schollarship and for financial support.

\section{REFERENCES}

DUARTE, H.S.S. et al. Development and validation of a set of standard area diagrams to estimate severity of potato early blight. European Journal of Plant Pathology, v.137, p.249-257, 2013. Available from: <http://link.springer.com/article/10.1007/s10658-013-0234-3>. Accessed: Jan. 25, 2016. doi: 10.1007/s10658-013-0234-3.

DUARTE, H.S.S. et al. Field resistance of potato cultivars to foliar early blight and its relationship with foliage maturity and tuber skin types. Tropical Plant Pathology, v.39, n.4, p.294-306, 2014. Available from: <http://www.scielo.br/pdf/tpp/v39n4/v39n4a04. pdf $>$. Accessed: Nov. 25, 2015.

GLASS, N.L. et al. The genetics of hyphal fusion and vegetative incompatibility in filamentous ascomycetes. Annual Review of Genetics, v.34, p.165-186, 2000. Available from: <http://www. annualreviews.org/doi/abs/10.1146/annurev.genet.34.1.165>. Accessed: Nov. 25, 2010. doi: 10.1146/annurev.genet.34.1.165.

KUMAR, S. Effect of nitogen on development of Altenaria blight caused by Alternaria solani of tomato (Lycopersicon esculentum) in rainy $\mathrm{Nd}$ winter seasons. Indian Journal of Agricultural Sciences, v.68 n.2, p.110-113, 1998. Available from: <http:// epubs.icar.org.in/ejournal/index.php/IJAgS/article/view/27325>. Accessed: Sept. 02, 2011.

MA, Z. et al. Resistance to azoxystrobim in Alternaria isolates from pistachio in California. Pesticide Biochemistry and Physiology, v.77, p.66-74, 2003. Available from: <http://www. sciencedirect.com/science/article/pii/S0048357503001044>. Accessed: Oct. 20, 2013. doi: 10.1016/j.pestbp.2003.08.002.

MCGUIRE, I.C. et al. Heterokaryon formation and parasexual recombination between vegetatively incompatible lineages in a population of the chestnut blight fungus, Cryphonectria parasitica. Molecular Ecology, v.14, p.3657-3669, 2005. Available from: <http://onlinelibrary.wiley.com/doi/10.1111/ j.1365-294X.2005.02693.x/abstract>. Accessed: Jan. 27, 2016. doi: 10.1111/j.1365-294X.2005.02693.x.

MICHEREFF, S.J. et al. Variabilidade de isolados de Alternaria brassicola no Estado de Pernambuco. Fitopatologia Brasileira, v.28, n.6, p.656-663, 2003. Available from: <http://www.scielo.br/ $\mathrm{pdf} / \mathrm{fb} / \mathrm{v} 28 \mathrm{n} 6 / \mathrm{a} 12 \mathrm{v} 28 \mathrm{n} 6 . \mathrm{pdf}>$. Accessed: Oct. 12, 2013.

MILGROOM, M.G. Recombination and the multilocus structure of fungal populations. Annual Review Phytopathology, v.34, p.457-477, 1996.

MSTAT-C. A software program for the design, management and analysis of agronomic research experiments. [S.1]: Michigan State University, 1991.

NACHMIAS, A. et al. The effects of Alternaria solani and Verticilium dahliaon potatoes growing in Israel. Potato Research, v.31, n.3, p.443-450, 1988. Available from: <http://link.springer. com/article/10.1007/BF02357881>. Accessed: Feb. 13, 2012. doi:10.1007/BF02357881.

NEDER, D.G. et al. Seleção de clones de batata com resistência múltipla à pinta preta e aos vírus X e Y. Ciência Rural, v.40, n.8, p.1702-1708, 2010. Available from: <http://www.scielo.br/pdf/cr/ v40n8/a667cr1907.pdf>. Accessed: Feb. 13, 2012. 
PONTECORVO, G. The parasexual cycle in fungi. Annual Review of Microbiology, v.10, p.393-400, 1956. Available from: $\quad<$ http://www.annualreviews.org/doi/abs/10.1146/annurev. mi.10.100156.002141>. Accessed: Jan. 27, 2016. doi: 10.1146/ annurev.mi.10.100156.002141.

PINTO, C.A.B.P. et al. Potato clones resistance to early and late blight. Crop Breeding and Applied Biotechnology, v.2, n.2, p.189-196, 2002. Available from: <http://www. sbmp.org.br/cbab/siscbab/uploads/c8128f42-4e80-e381.pdf >. Accessed: Oct. 12, 2013.

REIFSCHNEIDER, F.J.B. et al. Illustrated key for the evaluation of early blight of potatoes. Plant Protection Bulletin, v.32, p.91-94, 1984. Available from: $<$ http://www.scielo.br/scielo.php?script $=$ sci nlinks\&ref $=000096 \&$ pid $=$ s0102-0536199900020001700018\&lng $=$ en $>$. Accessed: Oct. 12, 2015.

RODRIGUES, T.T.M.S.; MIZUBUTI, E.S.G. Pinta preta: surge uma nova espécie. Revista Batata Show, v.24, p.14-16, 2009. Available from: <http://www.abbabatatabrasileira.com.br/images/ pdf/rbs_24.pdf>. Accessed: Oct. 15, 2012.

RODRIGUES T.T.M.S. et al. First report of Alternaria tomatophila and $\boldsymbol{A}$. grandis causing early blight on tomato and potato in Brazil. New Disease Reports, v.22, p.28-28, 2010. Available from: $<$ http://www.ndrs.org.uk/pdfs/022/NDR_022028.pdf $>$. Accessed: Oct. 15, 2012. doi: 10.5197/j.2044-0588.2010.022.028.

SAUPE, S.J. Molecular genetics of heterokaryon incompatibility in filamentous ascomycetes. Microbiology and Molecular
Biology Reviews, v.64, n.3, p.489-502, 2000. Available from: $<$ http://mmbr.asm.org/content/64/3/489.short>. Accessed: Oct. 15, 2011. doi: 10.1128/MMBR.64.3.489-502.2000.

SCOTT, A.J.; KNOTT, M. A cluster analysis method for grouping means in the analysis of variance. Bimetrics, v.30, n.3, p.507-512, 1974. Available from: <http://www.jstor.org/ stable/2529204?seq=1\#page_scan_tab_contents $>$. Accessed: Oct. 15,2011 . doi: $10.2307 / 2529204$.

STEWART, J.E. et al. Signatures of recombination in clonal lineages of the citrus brown spot pathogen, Alternaria alternata sensu lato. Phytopathology, v.103, n.7, p.741-749, 2013. Available from: $<$ http://apsjournals.apsnet.org/doi/pdfplus/10.1094/PHYTO-0812-0211-R>. Accessed: Jan. 27, 2016.

STRANDBERG, J.O. Alternaria species that attack vegetable crops: biology and options for disease management. Amsterdam: Elsevier, 1992. 175p.

VAN DER WAALS, J.E. et al. Genetic diversity among Alternaria solani isolates from potatoes in South Africa. Plant Disease, v.88, p.959-964, 2004. Available from: <http://apsjournals.apsnet.org/ doi/abs/10.1094/PDIS.2004.88.9.959>. Accessed: Oct. 15, 2011.

ZEIGLER, R.S. et al. Evidence of parasexual exchange of DNA in the rice blast fungus challenges its exclusive clonality. Phytopathology, v.87, p.284-294, 1997. Available from: <http://apsjournals.apsnet.org/action/ showLinks?system=10.1094\%2FPHYTO.1997.87.3.284\&isi=A1 997XN26600008>. Accessed: Jan. 27, 2016. 